\title{
Contemporary carbon balance and late Holocene carbon accumulation in a northern peatland
}

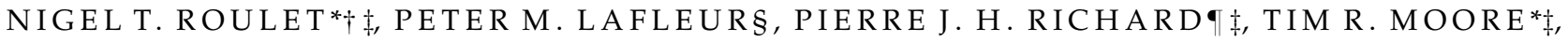 \\ ELYN R. HUMPHREYS $\|$ and JILL BUBIER ** \\ *Department of Geography, McGill University, 805 Sherbrooke Street West, Montreal, QC H3A 2K6, Canada, †McGill School of \\ Environment, McGill University, Montreal, QC, Canada, †The Global Environment and Climate Change Centre, McGill \\ University, Montreal, QC, Canada, §Department of Geography, Trent University, 1600 Westbank Drive, Peterborough, ON K9J \\ 7B8, Canada, Laboratoire Jacques-Rousseau, Département de géographie, Université de Montréal, C.P. 6128, Succursale \\ Centre-ville, Montréal, QC H3C 3J7, Canada, \|Department of Geography E Environmental Studies, Carleton University, \\ B349 Loeb Building, 1125 Colonel By Drive, Ottawa, ON K1S 5B6, Canada, ${ }^{* * E n v i r o n m e n t a l ~ S t u d i e s ~ P r o g r a m, ~ D e p a r t m e n t ~ o f ~}$ \\ Earth and Environment, Mount Holyoke College, Clapp Laboratory, 50 College Street, South Hadley, MA, 01075, USA
}

\begin{abstract}
Northern peatlands contain up to $25 \%$ of the world's soil carbon (C) and have an estimated annual exchange of $\mathrm{CO}_{2}-\mathrm{C}$ with the atmosphere of $0.1-0.5 \mathrm{Pg} \mathrm{yr}^{-1}$ and of $\mathrm{CH}_{4}-\mathrm{C}$ of $10-25 \mathrm{Tg} \mathrm{yr}^{-1}$. Despite this overall importance to the global $\mathrm{C}$ cycle, there have been few, if any, complete multiyear annual $\mathrm{C}$ balances for these ecosystems. We report a 6-year balance computed from continuous net ecosystem $\mathrm{CO}_{2}$ exchange (NEE), regular instantaneous measurements of methane $\left(\mathrm{CH}_{4}\right)$ emissions, and export of dissolved organic C (DOC) from a northern ombrotrophic bog. From these observations, we have constructed complete seasonal and annual $C$ balances, examined their seasonal and interannual variability, and compared the mean 6-year contemporary $C$ exchange with the apparent $C$ accumulation for the last 3000 years obtained from $C$ density and agedepth profiles from two peat cores. The 6-year mean NEE-C and $\mathrm{CH}_{4}-\mathrm{C}$ exchange, and net DOC loss are $-40.2 \pm 40.5( \pm 1 S D), 3.7 \pm 0.5$, and $14.9 \pm 3.1 \mathrm{~g} \mathrm{~m}^{-2} \mathrm{yr}^{-1}$, giving a 6-year mean balance of $-21.5 \pm 39.0 \mathrm{~g} \mathrm{~m}^{-2} \mathrm{yr}^{-1}$ (where positive exchange is a loss of $\mathrm{C}$ from the ecosystem). NEE had the largest magnitude and variability of the components of the $\mathrm{C}$ balance, but DOC and $\mathrm{CH}_{4}$ had similar proportional variabilities and their inclusion is essential to resolve the $\mathrm{C}$ balance. There are large interseasonal and interannual ranges to the exchanges due to variations in climatic conditions. We estimate from the largest and smallest seasonal exchanges, quasi-maximum limits of the annual $\mathrm{C}$ balance between 50 and $-105 \mathrm{~g} \mathrm{~m}^{-2} \mathrm{yr}^{-1}$. The net $\mathrm{C}$ accumulation rate obtained from the two peatland cores for the interval 400-3000 вP (samples from the anoxic layer only) were $21.9 \pm 2.8$ and $14.0 \pm 37.6 \mathrm{~g} \mathrm{~m}^{-2} \mathrm{yr}^{-1}$, which are not significantly different from the 6-year mean contemporary exchange.
\end{abstract}

Key words: carbon balance, DOC, methane, net ecosystem exchange, peatland

Received 4 May 2006 and accepted 30 June 2006

\section{Introduction}

Northern peatlands store between 200 and $450 \mathrm{Pg}$ of carbon (C; Gorham, 1991; Turunen et al., 2002) and the rate of $C$ accumulation over the last $6-8$ thousand has been estimated to be between 20 and $30 \mathrm{~g} \mathrm{C} \mathrm{m}^{-2} \mathrm{yr}^{-1}$

Correspondence: Nigel Roulet, Department of Geography, McGill University, 805 Sherbrooke St. W., Montreal, QC H3A 2K6 Canada. tel. +514 398 4945, e-mail: nigel.roulet@mcgill.ca

(C) 2007 The Authors

Journal compilation (C) 2007 Blackwell Publishing Ltd
(Gorham, 1991, 2003; Vitt et al., 2000; Turunen et al., $2002,2004)$. The $C$ balance of peatlands is of interest for several reasons. While the exchange of $\mathrm{CO}_{2}$ between peatlands and the atmosphere is a relatively small component of the contemporary terrestrial exchange $\left(\approx 0.1-0.5 \mathrm{Pg} \mathrm{yr}^{-1}\right.$ compared with $\approx 60 \mathrm{Pg}$ for the net terrestrial exchange Schimel, 1995), the fate of the large store of $\mathrm{C}$ in peatland is of concern (e.g. Moore et al., 1998) given the spatial pattern and magnitude of current and simulated changes in climate (Albritton \& 
Meira Filho, 2001). Peatland regions are experiencing, and are expected to experience in the future, well above average winter and summer temperatures and significantly greater winter precipitation. There is less agreement among the climate models of what might happen to summer precipitation in northern regions, particularly over northern Europe. The $\mathrm{C}$ balance of peatlands should also be of interest for palaeoclimatic modelling (e.g. Brovkin et al., 2002), since the store of $200-450 \mathrm{Pg}$ $\mathrm{C}$ exists because of a slow, varying, but persistent, C uptake over the last 10000 years.

There are far fewer measurements of the contemporary exchange of $C$ for northern peatlands than there are estimates of the past $C$ accumulation rate (CAR) derived from peat cores. The contemporary measurements are also more varied, but this is in part due to differences in methods of measuring the exchange, the completeness of the measurement of inputs and outputs, and the short duration of observations - seasons to 1 or 2 years. Most studies measure only net ecosystem $\mathrm{CO}_{2}$ exchange (NEE) using continuous micrometeorological methods (e.g. Shurpali et al., 1995; Suyker et al., 1997; Vourlitis \& Oechel, 1997; Nordstroem et al., 2001; Schulze et al., 2002; Friborg et al., 2003) or chamber methods combined with empirical interpolation and spatial extrapolation techniques (e.g. Whiting, 1994; Bubier et al., 1999). With only a very few exceptions, NEE measurements are rarely extended throughout the winter season or for more than 1 or 2 years (cf. Lafleur et al., 2001, 2003; Arneth et al., 2002; Aurela et al., 2002, 2004). Further, the loss of $C$ from the peatland by methane $\left(\mathrm{CH}_{4}\right)$ and dissolved organic $\mathrm{C}$ (DOC) export (cf. Waddington \& Roulet, 2000; Billett et al., 2004) are seldom included, even though they are of the same order of magnitude as the long-term rate of $\mathrm{C}$ accumulation (Gorham, 1991).

The annual change in $C, \Delta C_{\text {org}}$, for a peatland is given as

$$
\Delta C_{\text {org }}=\mathrm{NEP}+F_{\mathrm{CH}_{4}}+\text { netDOC } C_{E X},
$$

where NEP, net ecosystem production, is equal to the difference between the gross uptake and release of $\mathrm{CO}_{2}$ by photosynthesis and ecosystem respiration integrated over the year (i.e. -NEE), $F_{\mathrm{CH}_{4}}$ is the loss or gain of $\mathrm{C}$ through the annual integrated flux of $\mathrm{CH}_{4}$, and $n e t D O C_{E X}$ is the net gain or loss of DOC in water inputs and runoff (Lovett et al., 2006: where $F_{\mathrm{CH}_{4}}$ netDO$C_{E X}=E$ ). Gorham (1991) provided a range of estimates for the various components of $\approx-20$ to $-30,5$, and 5$20 \mathrm{~g} \mathrm{C} \mathrm{m}^{-2} \mathrm{yr}^{-1}$ for NEP, $F_{\mathrm{CH}_{4}}$, and netDOC $E X$, respectively: a negative sign indicates a loss to the atmosphere or a gain to the ecosystem. Gorham (1991) was also very clear that these estimates were based on an inadequate amount of data, and a mix of contemporary (e.g. $\mathrm{CH}_{4}$ fluxes and DOC losses) and inferred net primary production, NPP, from peat accumulation rates.

It is well established that many peatlands can lose a substantial amount of C during the winter (e.g. Alm et al., 1999a; Lafleur et al., 2003; Roehm \& Roulet, 2003). There is a wide range of annual NEE-C estimates from peatlands from a sink of -60 to a source of $90 \mathrm{~g} \mathrm{~m}^{-2} \mathrm{yr}^{-1}$, but most of these values are from shortterm studies. Long-term measurements in a single peatland show large year-to-year variability and switches among years from sources to sinks (Arneth et al., 2002; Aurela et al., 2002; Lafleur et al., 2003).

Most reported annual $\mathrm{C}$ exchanges are for fens (e.g. Lafleur et al., 1997; Suyker et al., 1997, Vourlitis \& Oechel, 1997; Alm et al., 1999b; Aurela et al., 2002; Schulze et al., 2002; Friborg et al., 2003) or for bogs where human activity, either on the peatland itself or in the surrounding catchment (e.g. Worrall et al., 2003; Billett et al., 2004), may have had some impact. Alm et al. $(1999 \mathrm{a}, \mathrm{b})$ report a C loss of $90 \mathrm{~g} \mathrm{C} \mathrm{m}^{-2} \mathrm{yr}^{-1}$ for a boreal bog due to an exceptionally dry summer, while Lafleur et al. (2003) report NEE-C ranging from $-60 \mathrm{~g} \mathrm{~m}^{-2} \mathrm{yr}^{-1}$ in wet years to near 0 in dry years for a raised bog. Arneth et al. (2002) found the NEE-C from a Siberian bog ranged from $\approx-60$ to $-36 \mathrm{~g} \mathrm{~m}^{-2} \mathrm{yr}^{-1}$, over a 2-year period, but the fluxes were measured only in the summer and the winter losses were modelled.

One of the unique characteristics of peatland ecosystems is that they retain a long-term, indirect record of $\mathrm{NEP}$ in the form of accumulating peat. Using age-depth relationships, peat densities, and $C$ contents from the deeper anoxic portion of peatlands (referred to as the catotelm Ingram, 1978, which starts deeper than -0.3 to $-0.5 \mathrm{~m}$ ) the average long-term apparent rate of $\mathrm{C}$ accumulation (LORCA) can be obtained (Tolonen \& Turunen, 1996; Clymo et al., 1998). While there have been many estimates of LORCA for peatlands (e.g. Vitt et al., 2000; Turunen et al., 2002; Gorham et al., 2003), as far as we know there has been no study that has compared a multiyear NEP and the CARs for the past for the same peatland. Schulze et al. (2002) compared NEP, ignoring $\mathrm{CH}_{4}$, and DOC losses, with recent apparent rates of $\mathrm{C}$ accumulation (RERCA; Turunen et al., 2004) from the top $0.5 \mathrm{~m}$ of peat for a Siberian appa mire. However, estimates of RERCA grossly overestimate LORCA (e.g. Turunen et al., 2004) as the peat is still actively decomposing in these surface layers.

The objectives of the study are: (1) to present an annual $C$ balance for a northern peatland over a 6-year period based on, as near as possible, complete-year measurements of all the major inputs and outputs to the ecosystem; and (2) to compare the contemporary multiyear mean $\mathrm{C}$ balance with the long-term $\mathrm{C}$ accumulation of the last few thousand years. 

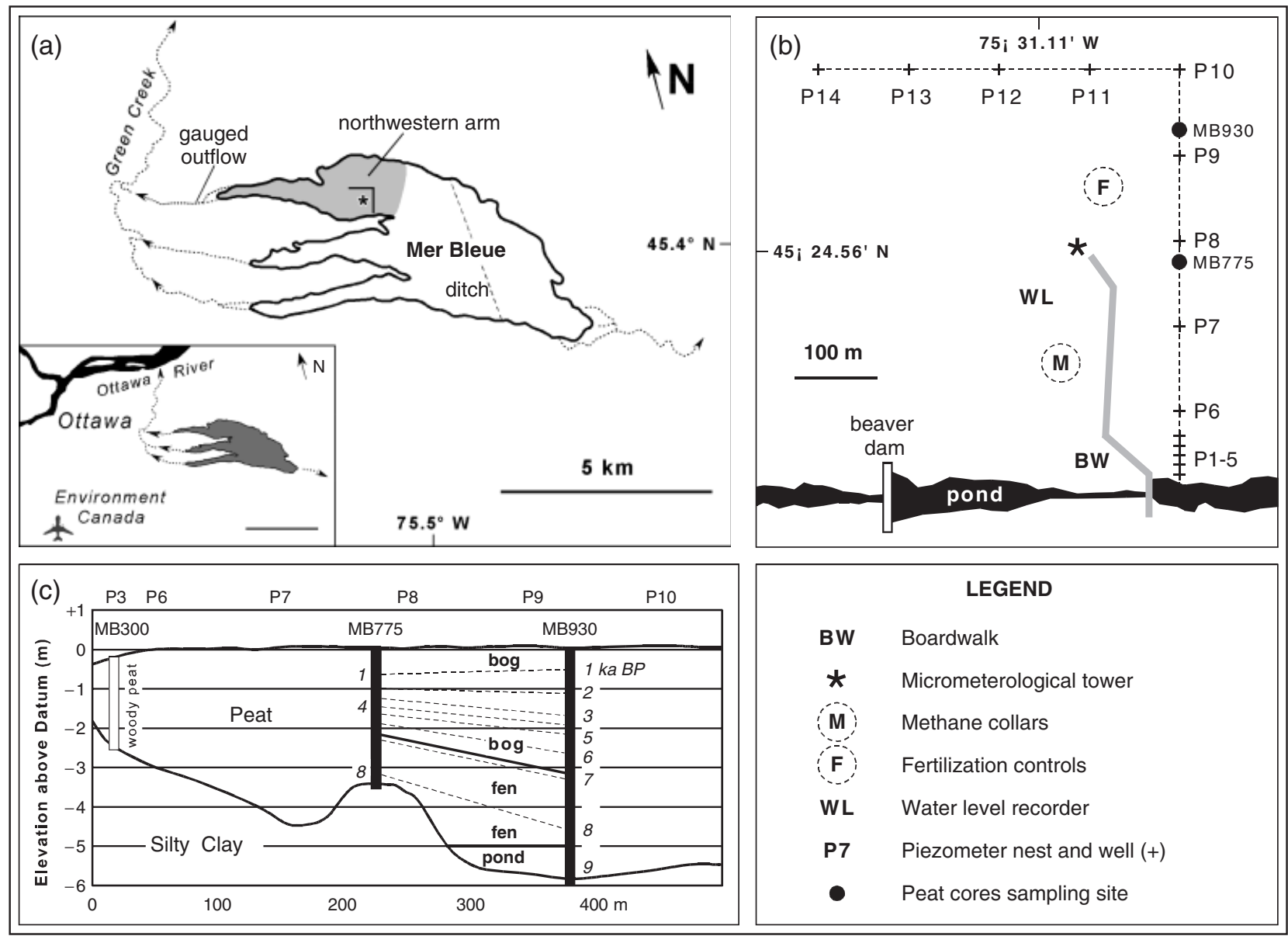

Fig. 1 Location of the study peatland (upper left), the location of the tower and where the peat cores were sampled (right panels), and the peat stratigraphy and age in cross section along the main axis piezometer network (lower left).

\section{Methods}

\section{Site description}

Mer Bleue peatland is located $10 \mathrm{~km}$ east of Ottawa, Ontario $\left(45.41^{\circ} \mathrm{N}\right.$ latitude, $75.48^{\circ} \mathrm{W}$ longitude, $69 \mathrm{~m}$ a.m.s.l.; Fig. 1). The climate of the region is cool continental, with a 30-year (1971-2000) mean annual temperature of $6.0 \pm 0.8^{\circ} \mathrm{C}$ and annual precipitation of $943 \mathrm{~mm}, 235 \mathrm{~mm}$ of which falls as snow between December and March. Total precipitation is fairly evenly spread among the 12 months, with a minimum of $58 \mathrm{~mm}$ in February and a maximum of $90 \mathrm{~mm}$ in July. The coldest month is January $\left(-10.8 \pm 2.9^{\circ} \mathrm{C}\right)$ and the warmest month is July $\left(20.9 \pm 1.1^{\circ} \mathrm{C}\right)$. The mean monthly air temperature is above $0^{\circ} \mathrm{C}$ from April through November, and above $10^{\circ} \mathrm{C}$ from May to September.

The Mer Bleue peatland lies in a postglacial channel system that was eroded into the floor of the former Champlain Sea basin. Regional ice retreat occurred shortly before 13200 years ago and the Lower Ottawa
River Lowlands were then invaded by Glacial Lake Iroquois (Anderson, 1988) depositing laminated silt and clay over sandy, silty gravel, and limestone outcrops. Around 13100 years ago (Anderson, 1988; Richard \& Occhietti, 2005), silty clay marine sediments 40-50 m thick were laid down over the glacio-lacustrine sediments as Champlain Sea rapidly invaded the isostatically depressed Saint-Lawrence River Lowlands. Marine waters lasted some 2500 years in the Central Lowlands, ending around 10600 years ago when freshwaters dominated again in the basin (Lampsilis Lake phase, Elson \& Elson, 1969). Modern contours of the Ottawa and St. Lawrence Rivers were attained around 7800 years ago. The postglacial channel system, now occupied by the Mer Bleue peatland basin, was carved by fluvial outbursts from the Ottawa River, during the emplacement of the early upper Great Lakes between 12000 and 9500 years ago. The oldest organic (lake) sediments in the Mer Bleue basin date back some 9000 years ago. The peatland formed over the past 8400 years, beginning as a fen, and switching to the bog 
phase ca. 7100-6800 cal. years BP (Auer, 1930; Mott \& Camfield, 1969; P. J. H. Richard, unpublished radiocarbon dates).

The present Mer Bleue peatland covers approximately $28 \mathrm{~km}^{2}$ and is roughly oval shaped with an east-west orientation. Two longitudinal lobes of fluvial sand/gravel material dissect the western end of the bog creating three separate arms (Fig. 1). The northwest arm, used in this study, is a slightly domed bog (Joyal, 1970), with peat depths varying from 5 to $6 \mathrm{~m}$ near the centre decreasing to $<0.3 \mathrm{~m}$ at the margins with a narrow band of beaver ponds surrounding the bog. The bog surface has a hummock-hollow microtopography. The dominant evergreen (Chamaedaphne calyculata, Ledum groenlandicum, Kalmia angustifolia), and deciduous (Vaccinium myrtilloides) shrubs have an average height of $0.2-0.3 \mathrm{~m}$ and leaf area index (LAI) of $\approx 1.3$ (Moore et al., 2002). Sedges (Eriophorum vaginatum) comprise a sparse cover and a few small trees (Picea mariana, Larix laricina, Betula populifolia) are present on hummocks. Hummocks and hollows are covered by Sphagnum mosses (S. capillifolium, S. magellanicum). Total aboveground and belowground biomass for vascular species, measured in 1999 and 2004, averaged $356 \pm 100 \mathrm{~g} \mathrm{~m}^{-2}$ (Moore et al., 2002) and $433 \mathrm{~g} \mathrm{~m}^{-2}$ (Bubier et al., 2006), and $1820 \pm 660 \mathrm{~g} \mathrm{~m}^{-2}$ (Moore et al., 2002) respectively, and Sphagnum capitulum biomass was $144 \pm 30 \mathrm{~g} \mathrm{~m}^{-2}$ (Moore et al., 2002) to $158 \mathrm{~g} \mathrm{~m}^{-2}$ (Bubier et al., 2006).

\section{Contemporary C balance measurements}

Measurements began at Mer Bleue in May 1998, but for the purposes of the calculation of the annual $\mathrm{C}$ balance, we consider the $C$ year to be from 1 November to 31 October: we present measurements from 1 November 1998 to 31 October 2004. In this section, we provide a brief but thorough summary of the measurements involved and indicate where more details can be found. NEE exchange measurements and data processing are described in Lafleur et al. $(2001,2003)$ but in our previous publications we used the period 1 June to 31 May for the $C$ year, so there are slight differences in NEE totals. The assessment of the runoff hydrology and water borne export of DOC are discussed in detail in Fraser et al. (2001a, b). We have not published the $\mathrm{CH}_{4}$ fluxes from Mer Bleue, but we used the same methods, procedures, instrumentation, and measurement protocols as described by Bubier et al. (2005). Our analysis of the $\mathrm{C}$ balance was restricted to the hydrologic catchment of the northwest arm of Mer Bleue: $\approx 4.8 \mathrm{~km}^{2}$ (Fraser et al., 2001b; Fig. 1). This constraint was necessary because NEE and $\mathrm{CH}_{4}$ flux are measured and computed on a areal (i.e. $\mathrm{m}^{-2}$ ) basis, thus, a catchment boundary is necessary to convert the mass flux of dissolved $\mathrm{C}$ measured at an outflow into a unit area loss.

$N E E$. The main instrument site was an $8 \mathrm{~m}$ tower located $250 \mathrm{~m}$ north of the southern edge of the bog (Fig. 1). Fetch surrounding the tower site was limited only to the south $(200-300 \mathrm{~m})$, the least frequent wind direction. For all other bearings, fetch ranged from 500 to $>1500 \mathrm{~m}$. The eddy covariance (EC) technique was used to measure the net flux of $\mathrm{CO}_{2}$ at a height of $3.0 \mathrm{~m}$ from the mean elevation of the hummock tops. Before 1 September 2000 the instrumentation consisted of a sonic anemometer-thermometer (model Solent 1012R3, Gill Instruments Ltd., Lymington, UK), and closed-path infrared gas analyser (IRGA, model 6252, LI-COR Inc., Lincoln, NB, USA), krypton hygrometer (Model KH20, Campbell Scientific, Inc., Logan, UT, USA), and a fine wire thermocouple. Air was drawn at $6.5 \mathrm{~L} \mathrm{~min}^{-1}$ through a sampling tube to the main instrument hut approximately $16.5 \mathrm{~m}$ away from the tower where the IRGA was stored. In September 2000 the IRGA was moved to an insulated, temperature-controlled box at the base of the tower with air drawn through a $4 \mathrm{~m}$ long sampling tube. Signals from all instruments were logged on a data logger (model CR7X, Campbell Scientific Inc., Logan, UT, USA) with a scan rate of $10 \mathrm{~Hz}$ and fluxes computed every $30 \mathrm{~min}$ from two $15 \mathrm{~min}$ subsampling intervals using the data logger covariance programme. Half-hour NEE was computed as the sum of the $\mathrm{CO}_{2}$ flux and the rate of change of $\mathrm{CO}_{2}$ storage in the air column below the height of the EC instrumentation. Details of flow corrections, WPL procedure, calibrations, quality control, and assurance are all outlined in Lafleur et al. (2003). Beginning January 2004 flux measurements were obtained using an upgraded system consisting of a model Solent R3-50 (Gill Instruments) sonic anemometer-thermometer and a model LI7000 closed-path IRGA (LI-COR) with air drawn through the $4 \mathrm{~m}$ sampling tube at $15 \mathrm{Lmin}^{-1}$. Digital signals from these sensors were recorded at $20 \mathrm{~Hz}$ using a computer. All $\mathrm{CO}_{2}$ fluxes for the 6-year period were calculated from the covariance of the $\mathrm{CO}_{2}$ mixing ratio and vertical velocity having undergone a three-axis co-ordinate rotation (Tanner \& Thurtell, 1969). The changes in the EC system in 2004 were expected to improve the $\mathrm{CO}_{2}$ flux measurements in part by reducing the loss of the high-frequency portion of the flux. The old and new systems were run concurrently and $30 \mathrm{~min} \mathrm{CO}_{2}$ fluxes obtained during rain-free periods in May and June 2004 were compared using linear regression. A correction factor of 1.25 for the old system fluxes $\left(n=1533, r^{2}=0.91\right)$ was found and applied to fluxes obtained before 
January 2004, reflecting the average proportion of flux lost due to damping of high-frequency fluctuations as a result of the previously lower flow rates in the intake tube, slower sampling rates and slower IRGA response rates. Throughout the 6-year period, calibration of the IRGA was done manually every 2-4 weeks. The Fluxnet-Canada measurement and processing protocols were used in our analysis (Protocols for EC Flux Measurements, pp. 8-17, in Fluxnet-Canada Measurement Protocols, August 2003: http://www.fluxnet-canada.ca/).

A variety of environmental measurements were made in support of the flux data (Lafleur et al., 2001, 2003). These measurements included above canopy incoming photosynthetically active radiation (PAR), air temperature at $2.0 \mathrm{~m}$ from the bog surface and soil temperatures from 0.01 to $2.5 \mathrm{~m}$ below the top of one hummock and one hollow with arrays of copperconstantan thermocouples embedded in wood dowels. Depth to the water table was measured in two wells (one in a hollow and one in a hummock) using a float and counterweight system attached to a potentiometer.

On average, $42 \%$ of the half-hour NEE measurements were removed from each year's data set due to instrument malfunction or quality control procedures described by Lafleur et al. (2003). Of the removed data, $31 \%$ were due to calm conditions when friction velocity fell below $0.1 \mathrm{~m} \mathrm{~s}^{-1}$ at night or during the cold season, or both; $62 \%$ were due to concerns over data quality and instrument malfunctions, and $7 \%$ were due to a C uptake at night or during the cold season when $5 \mathrm{~cm}$ soil temperatures were below freezing. We assumed under the latter condition both the moss and the bulk of the roots would be frozen thus inhibiting photosynthesis. In order to obtain seasonal and annual sums of NEE, the gaps in measurements were filled using the same procedure for each calendar year of the 6-year period. First, gaps of one and two halfhours were linearly interpolated (on average, $10 \%$ of the gaps). An exponential relationship was then derived for the negative of nighttime half-hour NEE (assumed to be equivalent to ecosystem respiration, ER) and $5 \mathrm{~cm}$ soil temperature greater than $0^{\circ} \mathrm{C}$. Estimates of ER using this relationship were adjusted to match the seasonal variations in ER using a multiplier found by regressing modelled values against measured values for 200 consecutive half-hour measurements (between 7 days and 2 months) moving through the year in increments of 40 half-hours (e.g. Barr et al., 2004). For daytime and nighttime periods during winter when $5 \mathrm{~cm}$ soil temperature was below $0{ }^{\circ} \mathrm{C}$, missing NEE was filled with the mean NEE from 200 consecutive half-hour measurements. Next, daytime estimates of gross ecosystem production (GEP) when soil temperatures were above $0{ }^{\circ} \mathrm{C}$ were estimated by adding measured and modelled ER to measured NEE. A rectangular hyperbolic relationship between GEP and PAR was evaluated for 15 June to 15 July of each year. GEP computed from this relationship was then adjusted to match the seasonal variations in GEP using the same procedure for ER above. Missing daytime NEE were filled using the difference between modelled ER and GEP.

The uncertainty associated with annual estimates of NEE was computed. We applied the Morgenstern et al. (2004) approach for an annual error estimate associated with a 20\% random error on each half-hour value of NEE computed using propagation of errors. The uncertainty from the empirical relationships used for gap-filling was assessed using a resampling technique with replacement for 1000 repetitions (see Humphreys et al., 2005). Finally, as the majority of the gaps are biased to periods of $C$ loss during the night or during the winter, the strategy for estimating ER for filling gaps was modified and used to recompute two additional sets of annual NEE. These included estimating ER using only a running mean and using a single-unadjusted annual relationship with $5 \mathrm{~cm}$ soil temperature.

Water borne loss of $C$. Discharge from Mer Bleue was measured at a culvert that passed under Anderson Road at the western end of the northwest arm (see Fig. 1 and Fraser et al., 2001a). Cross-sectional velocity was measured at the down stream end of the culvert using a Pygmy current meter (Gurley Precision Instruments, Troy, NY, USA) and discharge was calculated by the velocity-area method. Water level above the culvert was measured continuously using a float potentiometer connected to a data logger from 1998 through to 2002. Beaver activity (i.e dam construction and subsequent submergence of data loggers) meant that rating curves had to be recalibrated frequently. In 2002 a pressure transducer replaced the float-potentiometer measurements. Fraser et al. (2001b) determined there was a strong relationship between water table measured at the tower in the northwestern arm and discharge at the culvert outflow (Fig. 4a; Fraser et al., 2001b) and we used this relationship to estimate runoff during times when the water level record at the outflow was missing ( $\sim 25 \%$ of the time).

DOC in the outflow water was sampled weekly or more frequently in 1998, 1999, and 2003 and 2004, but sampling was sporadic between 2000 and 2003. Samples were placed in clean Nalgene bottles, filtered through $0.45 \mu \mathrm{m}$ membrane filters and the filtrate was analysed on a Shimadzu 5050 Total Organic Carbon analyser using Ultra-Zero air $\left(<1.0 \mathrm{ppm} \mathrm{CO}_{2}\right)$ as the carrier gas. Samples were acidified with $2 \mathrm{~N} \mathrm{HCl}$ to $\mathrm{pH} 2-4$ 

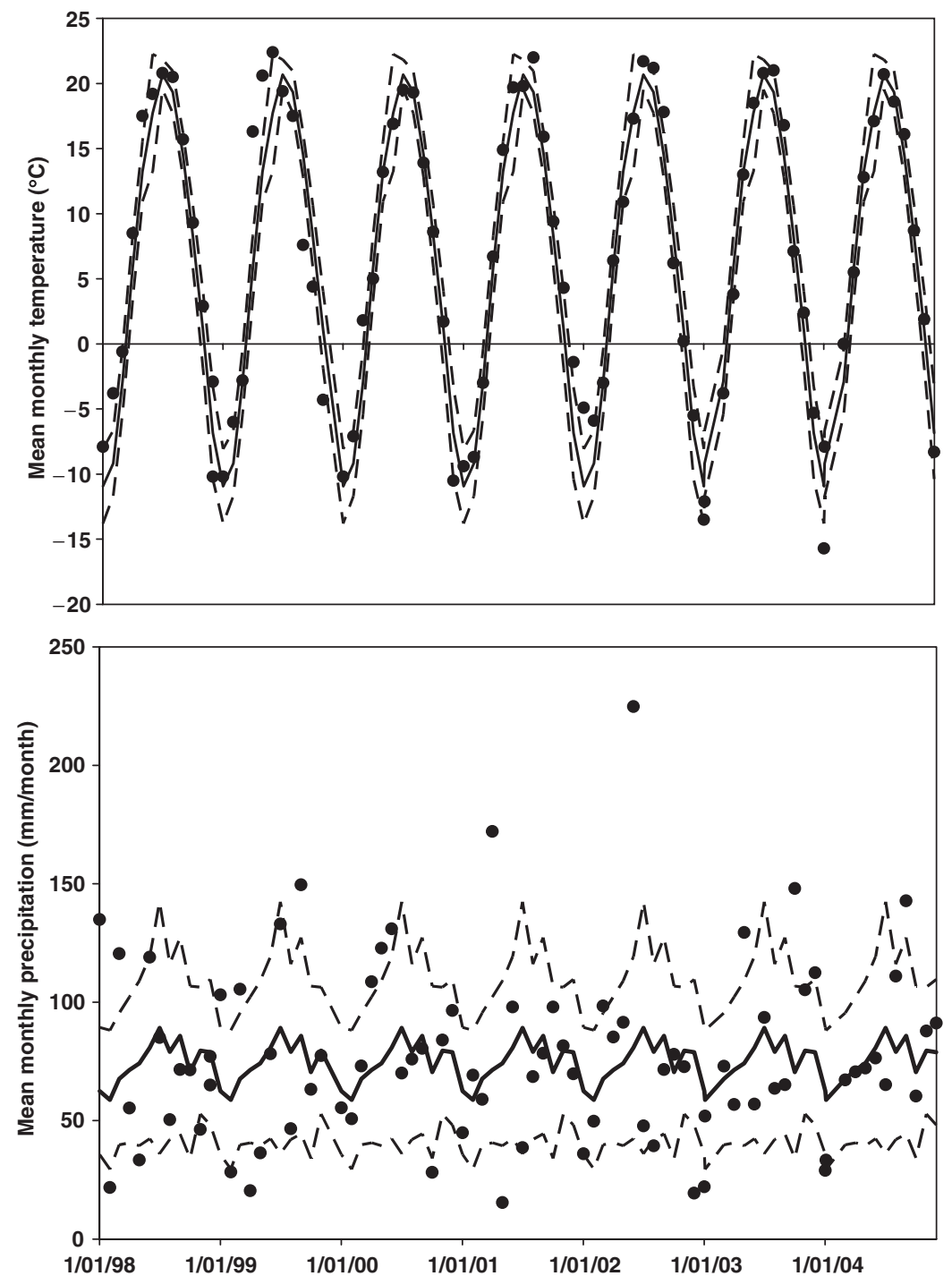

Fig. 2 Comparison between the mean monthly air temperature (top panel) and precipitation (lower panel) during the 6 years of the study (1998-2004) and the means derived from a 66-year period (1938-2004). All data were recorded at the Macdonald International Airport $12 \mathrm{~km}$ southwest of the Mer Bleue peatland. The circles are the monthly values, the solid line is the 66-year monthly means, and the dashed lines represent $1 \mathrm{SD}$ above or below the 66-year monthly means.

to convert carbonates to $\mathrm{CO}_{2}$ and sparged with $\mathrm{N}_{2}$ for $10 \mathrm{~min}$ to release the $\mathrm{CO}_{2}$. The samples were then combusted over a platinum catalyst at $680{ }^{\circ} \mathrm{C}$ to produce $\mathrm{CO}_{2}$ gas, which was measured by an infrared gas analyser. An average of three injections per sample were made but sometimes a maximum of six injections were performed to obtain a coefficient of variance $<5 \%$.

We chose Method-5 (Dawson et al., 2004) to calculate DOC export because, similar to Hope et al. (1997) and Dawson et al. (2004), we found no relationship between DOC and discharge (Fraser et al., 2001b). For the periods where there were too few DOC measurements to interpolate, we used the mean seasonal concentra- tions of DOC obtained from the 3 years when the sample size was large and the measured discharge for the desired time to estimate DOC loss. Fraser et al. (2001b) estimated overall error in annual DOC loss from Mer Bleue by combining the errors associated with discharge, the chemical analysis of DOC, and interpolation among sample points to be approximately $\pm 40 \%$.

We did not measure DOC input in rainfall, which is fairly small but not insignificant. To compute the input of DOC in precipitation, we assumed an average concentration of DOC of $2.0 \mathrm{mg} \mathrm{L}^{-1}$ based on the results of studies at Hubbard Brook (Likens \& Bormann, 1995) and near Montreal, Quebec (Dalva \& 
Moore, 1991) and multiplied this by the total amount of precipitation received at Mer Bleue during the period of interest.

$\mathrm{CH}_{4}$ fluxes. $\mathrm{CH}_{4}$ emissions were measured by a static chamber method at two locations in the northwest arm: one site, containing 20 collars, was between the tower and the peatland margin (Fig. 1: M), and the other site, containing 12 collars, was closer to the centre of the peatland (Fig. 1: F). A large number of measurements were made in 4 of the 6 years and few measurements were made in 1999 and 2001. $\mathrm{CH}_{4}$ emissions were measured using two different chambers (volumes 0.018 and $0.045 \mathrm{~m}^{3}$, and areas of 0.05 and $0.03 \mathrm{~m}^{2}$ ) placed on water-sealed collars inserted $\approx 0.1 \mathrm{~m}$ into the peat (see Bubier et al., 2005). The air in the enclosure was sampled every $5 \mathrm{~min}$ for $25 \mathrm{~min}$ through a septum and stopcock, and the samples were analysed on a Shimadzu Mini II gas chromatograph (Shimadzu Scientific Instruments, Columbia, MD, USA) equipped with a flame ionization detector. The GC was calibrated for each sample period with three standards and periodically checked to ensure the calibration had a reproducibility of $\pm 1 \%$. The fluxes of $\mathrm{CH}_{4}$ were calculated from the slope of the regression between $\mathrm{CH}_{4}$ concentration and time.

The seasonal emissions of $\mathrm{CH}_{4}$ for each location were estimated by interpolating between sample dates. It was assumed for the purposes of determining the annual fluxes that the annual emission period was 180 days. It has been shown that in many peatlands there is a winter flux of $\mathrm{CH}_{4}$ that can amount to between $2 \%$ and $10 \%$ of the annual $\mathrm{CH}_{4}$ emissions (e.g. Melloh \& Crill, 1996; Alm et al., 1999b) but for the purposes of our $\mathrm{C}$ balance we have assumed that winter fluxes were zero.

\section{Past $C$ balance measurements}

The many past CARs obtained from peat core studies are less variable than contemporaneous $\Delta C_{\text {org }}$ estimates due to the numbers of years compressed into even $1 \mathrm{~cm}$ increments of cores and the low number of cores taken in an individual peatland. When multiple cores are taken in a single peatland, the estimates of CAR can vary considerably between cores (Korhola et al., 1996; Lavoie \& Richard, 2000a, b). We sampled two peat cores from the area near the tower dominated today by Sphagnum moss and C. calyculata, to reconstruct the palaeoecology of the peatland and to determine the temporal variability in LORCA (Fig. 1). The upper $1.44 \mathrm{~m}$ (core MB930) and $2.00 \mathrm{~m}$ (core MB775) were sampled with a $2 \mathrm{~m}$ long and $0.1 \mathrm{~m}$ inner diameter Coüteaux sampler (Coüteaux, 1962): the remaining

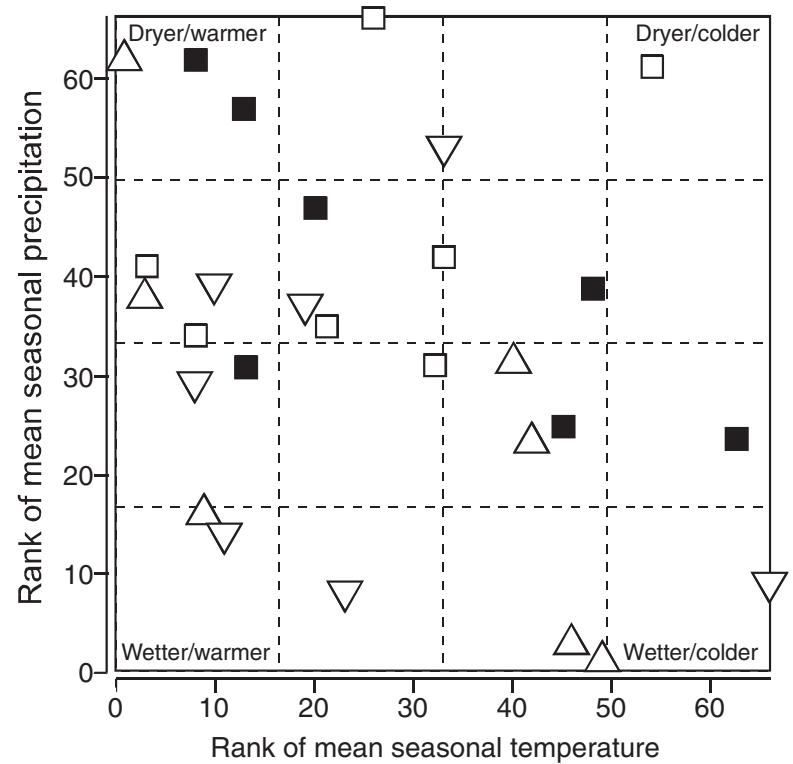

$\square$ Winter : November to March

$\triangle$ Spring: April to June

Fig. 3 Rank of the seasonal temperature and precipitation for the 6 years of the study, 1998-2004, relative to the rank of all seasons from the full 66 years of record (1938-2004). The winter, spring, summer, and autumn are November-March, April-June, July-August, and September-October, respectively.

$1.5-3.0 \mathrm{~m}$ was sampled with a $1 \mathrm{~m}$ long, $0.075 \mathrm{~m}$ inner diameter Russian corer (Jowsey, 1966) yielding hemicylindric cores, down to $5.97 \mathrm{~m}$ (MB930) and $3.47 \mathrm{~m}$ (MB775). CARs were established from an age-depth relationship combined with fine resolution measurements of density and $C$ concentration in the cores.

Fifteen age determinations were used for core MB930, either from radiocarbon dates $(N=5)$ or from palynostratigraphical correlation with other radiocarbon dated pollen diagrams in the Montreal-Ottawa area $(N=10)$. The age for core MB775 was obtained through correlation against the pollen diagram from core MB930 $(N=8$ palynostratigraphically correlated samples). Samples $\left(1 \mathrm{~cm}^{3}\right)$ of fresh peat were dried at $105^{\circ} \mathrm{C}$, weighed, and ignited at $600{ }^{\circ} \mathrm{C}$, to determine density and organic matter content (Dean, 1974; Beaudoin, 2003). C concentration was estimated to be $50 \%$ of the organic matter content. Turunen et al. (2004) analysed the top $0.60 \mathrm{~m}$ for 48 cores from 24 different bogs in eastern Canada and obtained a mean of $46 \%$. We used this C concentration in our calculations. Measurements from core MB930 were made every $0.01 \mathrm{~m}$ from the surface to $1.44 \mathrm{~m}$, and every $0.04 \mathrm{~m}$ from 1.44 to $5.97 \mathrm{~m}$ and for the MB775 core, every $0.02 \mathrm{~m}$ from 0 to $2.00 \mathrm{~m}$, and every $0.04 \mathrm{~m}$ 

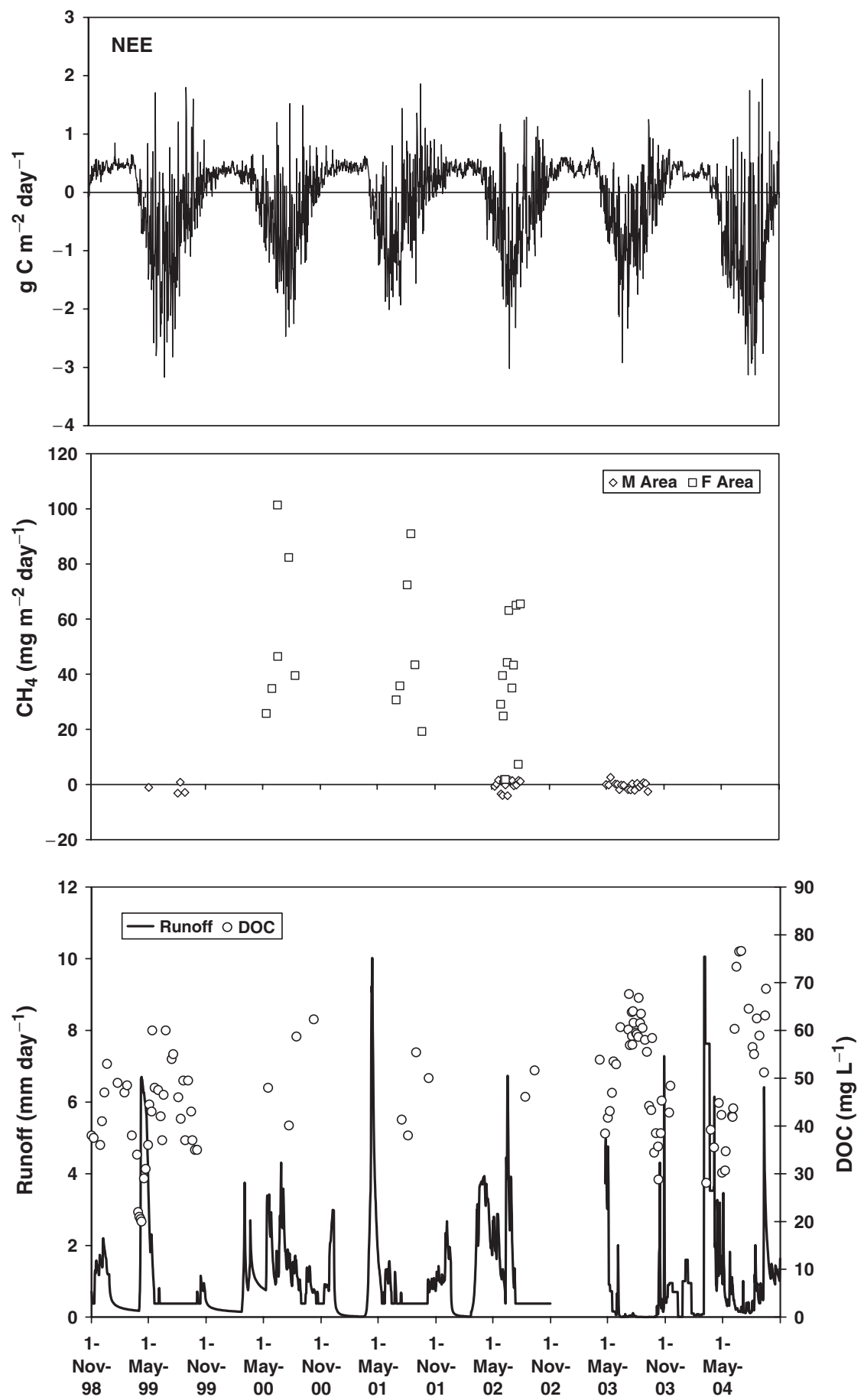

Fig. 4 Time series of the eddy covariance net ecosystem $\mathrm{CO}_{2}$ exchange (NEE; direct observations and in-filled; top panel), instantaneous $\mathrm{CH}_{4}$ flux (middle panel), and discharge and dissolved organic carbon (DOC) concentrations at the outflow of the Mer Bleue peatland (bottom panel). In the case of the $\mathrm{CO}_{2}$ exchange the atmospheric sign convention as been adopted - i.e. a negative is a loss from the atmosphere or a gain by the peatland.

from 200 to $347 \mathrm{~cm}$ for the MB930 core. Long-term rates of $\mathrm{C}$ accumulation (LORCA) were calculated using a smoothed, age-depth model for each core, the estimated $\mathrm{C}$ concentration for each sample, and the interpolated deposition time of each depth increment (e.g. either 0.01 or $0.04 \mathrm{~m}$ ). LORCA was determined for the period between 3000 and 400 years ago to avoid including the acrotelm portion of the cores where the CARs are 

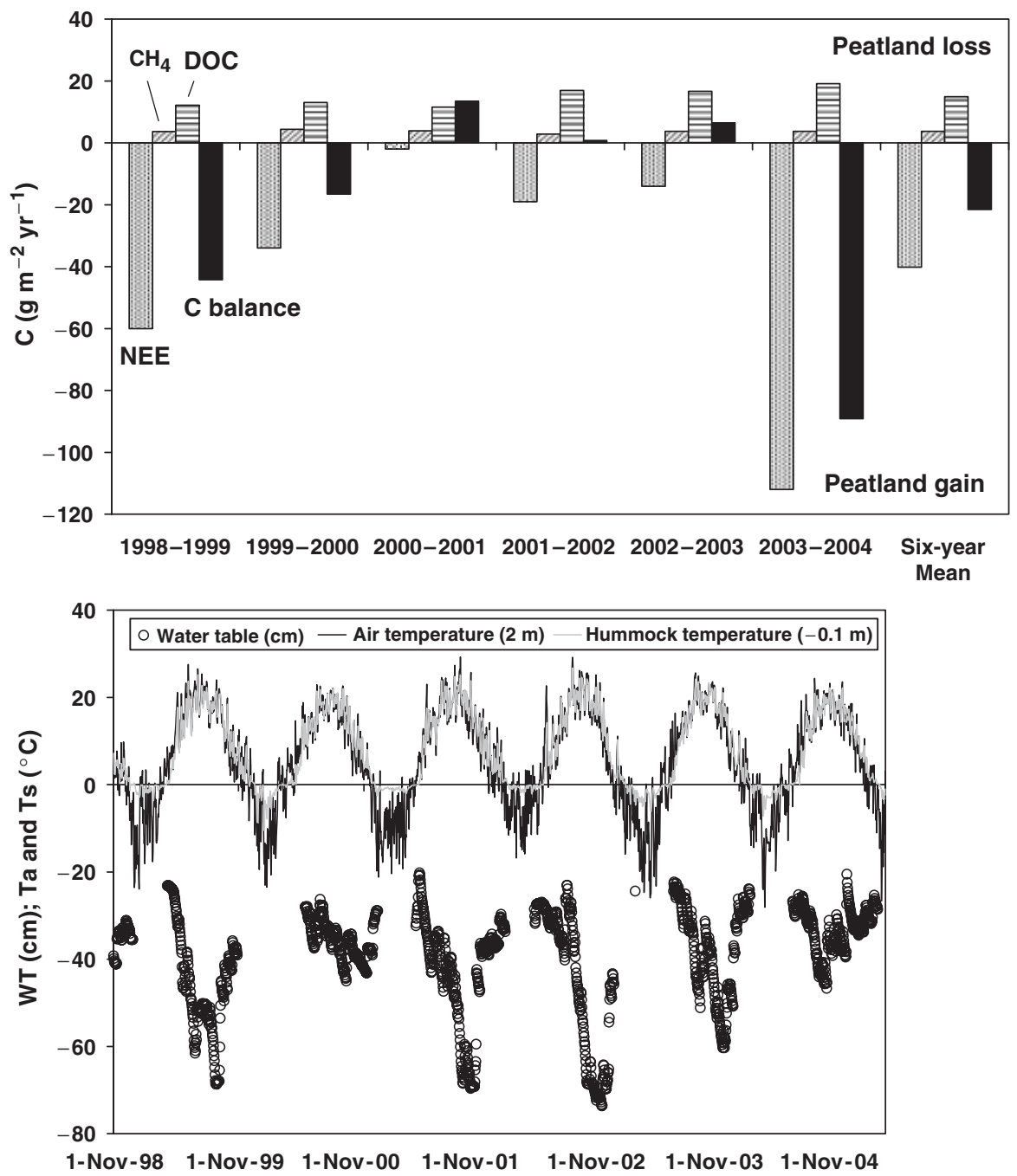

Fig. 5 Components of the annual carbon balance (top panel) and the trends on air, hummock peat temperature and water table for the 6 years (1 November 1998 to 31 October 2004) for the Mer Bleue peatland (bottom panel).

not representative of the long-term rates because the peat is still actively decomposing in the oxygenated, unsaturated zone (Turunen et al., 2004). Peat age of 400 years corresponds to depths of $0.32 \mathrm{~m}$ in core MB930 and $0.45 \mathrm{~m}$ in core MB775, and zero depth corresponds to the base of living Sphagna. Deposition time within this window varies between 16 and $42 \mathrm{yr} \mathrm{cm}^{-1}$ for the MB930 core and between 19 and $31 \mathrm{yrcm}^{-1}$ for the MB775 core.

\section{Results}

\section{Annual and seasonal climate variations}

The climate for 1998-2004 was quite variable (Fig. 2): over half the mean seasonal temperatures and total precipitation were greater than $1 \mathrm{SD}$ from the long-term mean and totals for the 66-year record at the Ottawa Macdonald-Cartier International Airport $\left(45.19^{\circ} \mathrm{N}\right.$ latitude, $75.40^{\circ} \mathrm{W}$ longitude, $114 \mathrm{~m}$ a.m.s.l.), approximately $12 \mathrm{~km}$ southwest of the Mer Bleue peatland (Fig. 1). We ranked the seasonal temperature and precipitation within the 66 years of record (Fig. 3). The winters of 2002 and 2004, the spring of 1999, the summers of 2001 and 2002, and autumn 2000 received significantly (i.e. in the upper or lower quartile) less precipitation, while the springs of 2000 through 2002, and the autumns of 1999, 2003, and 2004 experienced precipitation closer to the norm. Only three seasons were colder than normal (summer and autumn 1999, and winter 2002), while in 11 of the remaining 21 seasons, or $45 \%$ of the study period, the temperatures were in the top quartile. Six out of a possible 24 seasons experienced both large temperature and precipitation anomalies (drier/wetter and warmer/cooler). 


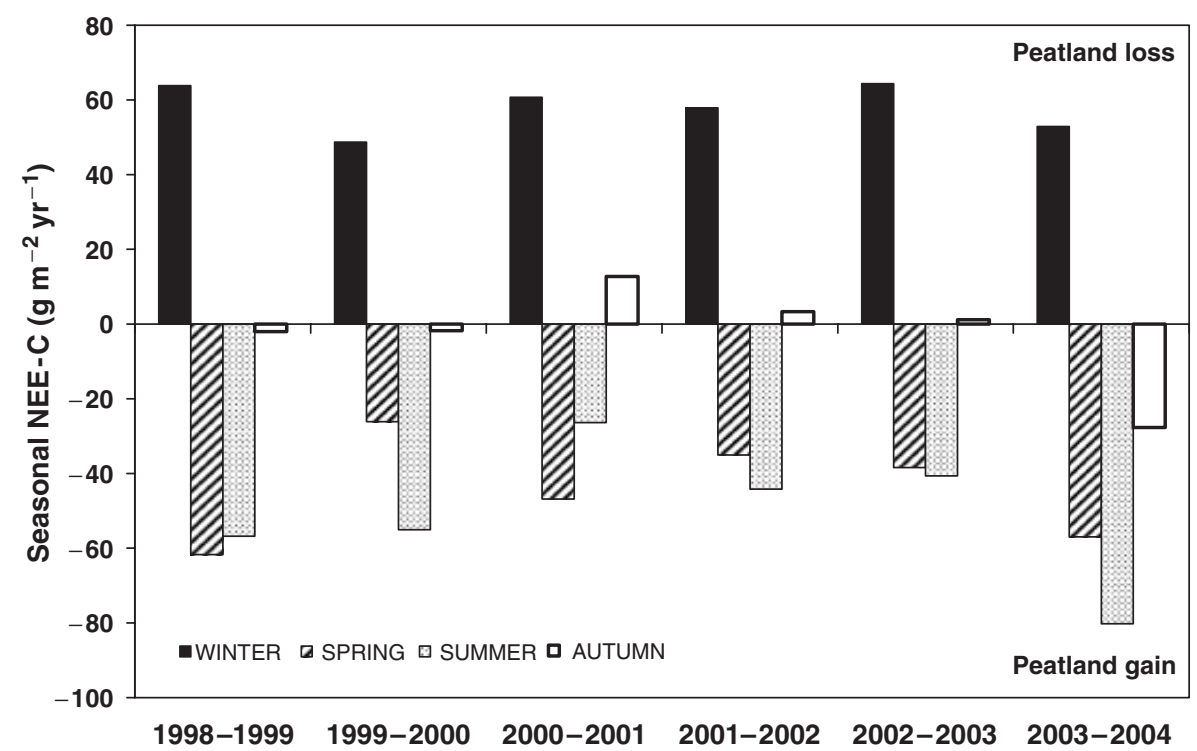

Fig. 6 Seasonal NEE from 1 November 1998 to 31 October 2004 for the Mer Bleue peatland. The seasons were defined in the caption for Figure 3.

\section{Contemporary annual C balance}

The NEE, $\mathrm{CH}_{4}$ fluxes, runoff, and DOC concentration for the period 1 November 1998 to 31 October 2004, for the Mer Bleue peatland are shown in Fig. 4. NEE-C ranges from a maximum uptake $>2.5 \mathrm{~g} \mathrm{~m}^{-2} \mathrm{day}^{-1}$ in June or early July in each year to a maximum loss of $>1 \mathrm{~g} \mathrm{~m}^{-2}$ day $^{-1}$ (Fig. 4a). Mer Bleue took up $\mathrm{CO}_{2}$ between mid-April to mid-October. The shift from the winter loss of $\mathrm{CO}_{2}$ to net uptake in the spring was well defined in most years (April $16 \pm 5$ days), but the switch from net uptake to release in the autumn (October $3 \pm 17$ days) was more variable among years. Mer Bleue released $\mathrm{CO}_{2}-\mathrm{C}$ over the winter [mean loss $58.1 \pm 6.2( \pm 1 \mathrm{SD}) \mathrm{g} \mathrm{m}^{-2} \mathrm{t}^{-1}$; maximum 64.4, minimum 48.7 , where ' $t$ ' indicates the duration of the season in question which varied among years] and experienced an uptake through the spring, summer, and autumn (mean net uptake $-97.1 \pm 38.7 \mathrm{~g} \mathrm{~m}^{-2} \mathrm{t}^{-1}$; maximum -164.8 , minimum -76.0). The annual cumulative NEE-C ranged from a minimum of -2 (2000-2001) to a maximum of $-112 \mathrm{~g} \mathrm{~m}^{-2} \mathrm{yr}^{-1}$ (2003-2004) and the 6-year mean annual cumulative NEE-C was $-40.2 \pm 40.5 \mathrm{~g} \mathrm{~m}^{-2} \mathrm{yr}^{-1}$ (Fig. 5).

The $\mathrm{CH}_{4}$ flux from Mer Bleue ranged from a maximum uptake of $-4.1 \mathrm{mg} \mathrm{m}^{-2}$ day $^{-1}$ to a maximum emission of $101.4 \mathrm{mg} \mathrm{m}^{-2}$ day $^{-1}$. The $\mathrm{CH}_{4}$ flux differed considerably between the two sites (Fig. 4b). In the area $\mathrm{M}$ the $\mathrm{CH}_{4}$ fluxes were on average a small uptake (mean $-0.1 \pm 3.6 \mathrm{mg} \mathrm{m}^{-2}$ day $^{-1}$; maximum 21.2, minimum $-4.1)$. However, closer to the centre of the peatland (area $F$ ) there was a consistent net emission (mean $43.5 \pm 23.2 \mathrm{mg} \mathrm{m}^{-2}$ day $^{-1}$; maximum 101.4, minimum -1.8). To estimate the annual flux of $\mathrm{CH}_{4}$ we assumed, based on visual inspection of various images of Mer Bleue, that these separate areas made up $40 \%$ and $60 \%$ of the surface area of the bog. The annual loss of $\mathrm{C}$ as $\mathrm{CH}_{4}$ ranged from 2.8 to $4.4 \mathrm{~g} \mathrm{~m}^{-2} \mathrm{yr}^{-1}$, with a 6-year mean of $3.7 \pm 0.5 \mathrm{~g} \mathrm{~m}^{-2} \mathrm{yr}^{-1}$ (Fig. 5).

We have 5 years of reasonably good estimates of runoff and 3 years of DOC concentration (1998-1999 and 2002-2004; Fig. 4c). The arithmetic mean concentration of DOC at the peatland outflow was $47.5 \pm 12.6 \mathrm{mg} \mathrm{L}^{-1}$ (maximum 76.6, minimum 20.0). There was a marked seasonal pattern in DOC concentration, from lower in the spring when runoff was greatest $\left(20.0-47 \mathrm{mg} \mathrm{L}^{-1}\right)$ to higher in the summer during periods of negligible flow $\left(47-76 \mathrm{mg} \mathrm{L}^{-1}\right)$. Runoff varied considerably from year-to-year (mean $391 \pm 67 \mathrm{~mm} \mathrm{yr}^{-1}$; maximum 472, minimum 316), and followed differences in annual precipitation. Over 55\% of the annual runoff occurred in March and April from snow melt. Combining runoff and DOC concentrations yielded a net mean annual loss of $\mathrm{C}$ via DOC export of $16.4 \pm 3.4 \mathrm{~g} \mathrm{~m}^{-2} \mathrm{yr}^{-1}$ (maximum 21.0, minimum 13.2). The mean annual input of DOC in precipitation was estimated to be $1.8 \pm 0.1 \mathrm{~g} \mathrm{~m}^{-2} \mathrm{yr}^{-1}$ (maximum 1.9, minimum 1.6), giving a mean annual net DOC export of $14.9 \pm 3.1 \mathrm{~g} \mathrm{~m}^{-2} \mathrm{yr}^{-1}$ (maximum 19.1, minimum 11.5; Fig. 5).

Combining the annual import and export of $\mathrm{C}$ for the Mer Bleue peatland resulted in a mean 6-year $\mathrm{C}$ balance 


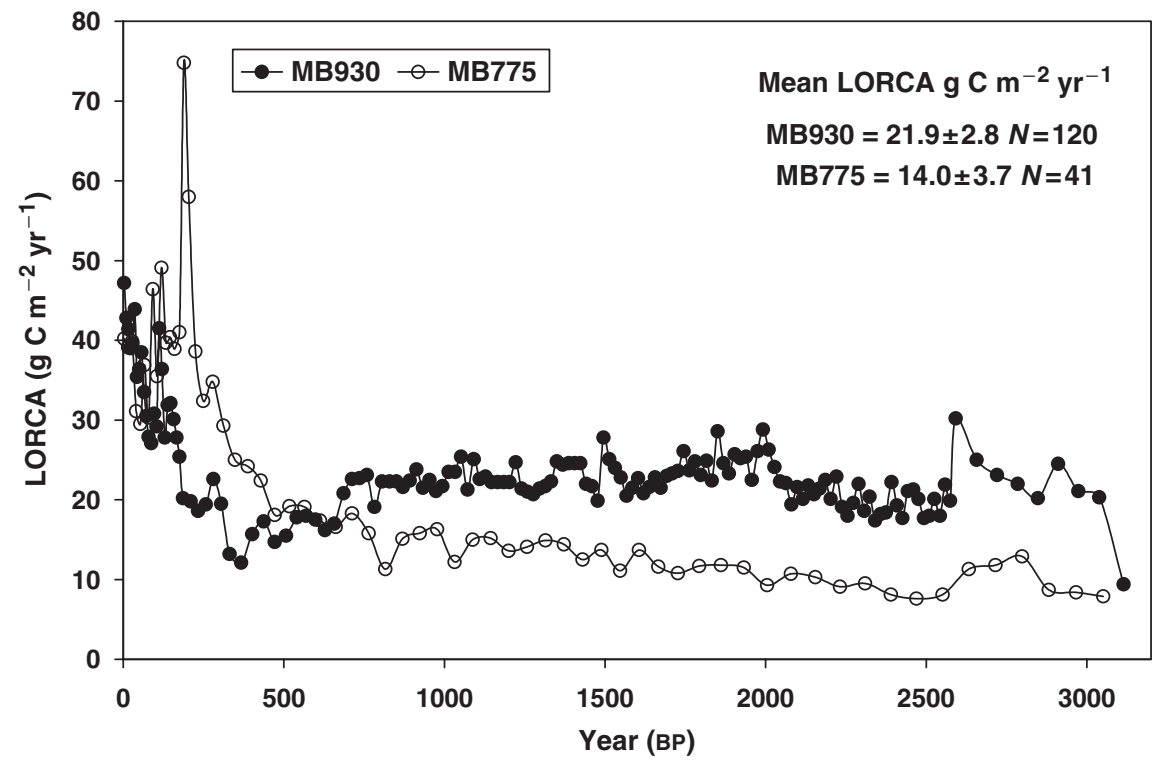

Fig. 7 Average long-term apparent rate of carbon accumulation for the last 3000 years for the Mer Bleue peatland. The mean and standard deviations of long-term apparent rate of $\mathrm{C}$ accumulation (LORCA) are based on accumulation rates from below the acrotelm/ catotelm boundary only (i.e. $>400$ вр).

of $-21.5 \pm 39.0 \mathrm{~g} \mathrm{~m}^{-2} \mathrm{yr}^{-1}$ (Fig. 5). In 3 of the 6 years (2000-2001, 2001-2002, 2002-2003) the net $C$ loss at Mer Bleue ranged from 13.5 to $0.8 \mathrm{~g} \mathrm{~m}^{-2} \mathrm{yr}^{-1}$. All 3 of these years experienced quite low water tables from mid to late summer through into the autumn (Fig. 5). In the other 3 years, the net sink for $C$ ranged from -16.5 to $-89.2 \mathrm{~g} \mathrm{~m}^{-2} \mathrm{yr}^{-1}$ : two of which had higher water tables throughout the summer and into the autumn. NEE is the largest and most variable $(\mathrm{CV}=100 \%)$ component of the balance. However, while the loss of $\mathrm{C}$ by $\mathrm{CH}_{4}$ in Mer Bleue is quite small, the loss of $\mathrm{C}$ via DOC export is an important component of the annual $\mathrm{C}$ balance. In fact, in no year was the NEE positive, but in 3 years the loss of $\mathrm{C}$ via DOC resulted in there being a net loss of $\mathrm{C}$ from the Mer Bleue peatland. $\mathrm{CH}_{4}$ and DOC losses equate, on average, to $9 \%$ and $37 \%$ of mean NEE. If $\mathrm{CH}_{4}$ and DOC were ignored, the uptake of $\mathrm{C}$ in the Mer Bleue peatland would be overestimated by $40 \%$ to $80 \%$ in those years that net uptake occurred, and a net loss of $\mathrm{C}$ would not have been estimated for the other 3 years.

\section{Reliability of the 6-year mean $C$ balance}

Given the large variation in the $C$ exchanges we have measured it is important to consider the robustness of the 6-year mean exchange. The uncertainty associated with each estimate of annual NEE varies depending on the nature of the error. For random errors, the uncertainty in the $\mathrm{C}$ balance is less than $1.6 \mathrm{~g} \mathrm{~m}^{-2} \mathrm{yr}^{-1}$. The $95 \%$ confidence intervals on annual estimates of NEE computed with the resampling technique gives an in- dication of the influence of individual $\mathrm{C}$ measurements on the parameters of the empirical relationships used for gap-filling were all less than $\pm 2 \mathrm{~g} \mathrm{~m}^{-2} \mathrm{yr}^{-1}$. The systematic biases associated with the gap-filling strategy resulted in the greatest uncertainties. Estimating ER using only a running mean generally resulted in less annual $\mathrm{C}$ uptake by $22 \pm 4 \mathrm{~g} \mathrm{~m}^{-2} \mathrm{yr}^{-1}$ on average (NEE$\mathrm{C}$ increased by $13-39 \mathrm{~g} \mathrm{~m}^{-2} \mathrm{yr}^{-1}$ ). By using a single unadjusted annual relationship with $5 \mathrm{~cm}$ soil temperature, annual $\mathrm{C}$ uptake was generally greater by $7 \mathrm{~g} \mathrm{~m}^{-2} \mathrm{yr}^{-1}$ (NEE-C decreased by 33 to $-5 \mathrm{~g} \mathrm{~m}^{-2} \mathrm{yr}^{-1}$ for the 6 years). In most cases, the differences among years remained similar regardless of the gap-filling technique used.

Although we reduced the uncertainty in the observations as much as possible there was still a large uncertainty associated with the inherent variability in the $\mathrm{C}$ exchanges. To significantly reduce the SD many more years of observations would be needed. For example, assuming that the variance of the $C$ balance we observed is representative of the 'normal' range, to reduce the SD to approximately equal to that of the mean $\Delta C_{\text {org }}$ would require $\approx 20$ years of observations. The variability is a function of different weather conditions from year-to-year and season-to-season. An important question for determining the robustness of our observations is whether the period of measurement covers the possible range of climatic conditions. Ecosystems do not respond to changes in mean conditions as much as to changes in seasonal conditions, such as warmer/colder winters and depth of snow, and warm/cooler, wetter/ 
drier spring, summer, and autumn. Partitioning the annual NEE into seasonal NEE indicates there are large differences among the seasons over the 6 years (Fig. 6). The seasonal variation, expressed as SDs, of the winter, spring, summer, and autumn $C$ exchanges are respectively $\pm 6.2,13.6,18.2$, and $13.5 \mathrm{~g} \mathrm{~m}^{-2} \mathrm{t}^{-1}$. Winter showed the least variability. To approximate a potential maximum and minimum NEP, we combined all the seasons with the lowest and the maximum $C$ exchange and this produced a range of -25 to $121 \mathrm{~g} \mathrm{~m}^{-2} \mathrm{yr}^{-1}$. We then combined this with the maximum and minimum losses for $\mathrm{CH}_{4}$ and DOC to bracket the possible $\Delta C_{\text {org }}$ between 50 and $-105 \mathrm{~g} \mathrm{~m}^{-2} \mathrm{yr}^{-1}$.

\section{Long-term C accumulation}

Cores MB930 and MB775 estimate average, LORCA (obtained from samples below the acrotelm-catotelm boundary) of $21.9 \pm 2.8$ and of $14.0 \pm 3.7 \mathrm{~g} \mathrm{C} \mathrm{m}^{-2} \mathrm{yr}^{-1}$, respectively, between 3000 and 400 years ago (Fig. 7). The lower LORCA for MB775 is due to the position of the (overall) shorter core on a ridge at the bottom of the Mer Bleue basin (Fig. 1), affecting the long-term rate of decomposition until about 1800 years ago, after which both cores showed similar vegetational development.

\section{Discussion}

\section{Six-year C balance of Mer Bleue}

Our measurements show that the portion of Mer Bleue we examined has an average annual contemporary $\mathrm{C}$ accumulation around $21 \mathrm{~g} \mathrm{~m}^{-2} \mathrm{yr}^{-1}$, but the peatland $\mathrm{C}$ balance is inherently variable ranging from a source of 14 to a sink of $89 \mathrm{~g} \mathrm{~m}^{-2} \mathrm{yr}^{-1}$. In only one of the 6 years (1999-2000) was the annual C balance $\left(-16.5 \mathrm{~g} \mathrm{~m}^{-2} \mathrm{yr}^{-1}\right)$ close to the 6-year mean. The large SD clearly demonstrates that attempting to establish the contemporary $C$ balance of a peatland based on 1-2 years of data is not reliable. Equally important, our results show that ignoring the $\mathrm{CH}_{4}$ and net DOC losses of $\mathrm{C}$ will lead to over estimating the $\mathrm{C}$ sink between $\approx 16$ and $23 \mathrm{~g} \mathrm{~m}^{-2} \mathrm{yr}^{-1}$, which encompasses the value of the 6-year mean $\mathrm{C}$ sink. In our study, the $\mathrm{CH}_{4}$ flux is a much smaller loss than DOC. The $\mathrm{CH}_{4}$ flux is similar to those reported for many other bogs (e.g. $1-8 \mathrm{~g} \mathrm{~m}^{-2} \mathrm{yr}^{-1}$ ), but lower than the $\mathrm{CH}_{4}$ losses reported for wetter, mineral-rich peatlands (e.g. 3-30 $\mathrm{g} \mathrm{m}^{-2} \mathrm{yr}^{-1}$; Moore \& Roulet, 1995; Nilsson et al., 2001). The DOC export from Mer Bleue is consistent with that observed for other peatlands (e.g. Waddington \& Roulet, 1997; Worrall et al., 2003; Billett et al., 2004) and to that originally inferred by Gorham (1991).
To the best of our knowledge, this is the first full $\mathrm{C}$ balance constructed from multiyear measurements on any peatland, where the components $\mathrm{NEE}, \mathrm{CH}_{4}$, and DOC have been measured for more than 2 years. Waddington \& Roulet $(1997,2000)$ estimated a C balance for a poor fen in northern Sweden based on chamber measurements of $\mathrm{CO}_{2}, \mathrm{CH}_{4}$ and estimates of groundwater flow and DOC concentrations. The NEE$\mathrm{C}, \mathrm{CH}_{4}-\mathrm{C}$, and DOC inputs and outputs between the 2 years of study were -10.3 and $-3,4.1$ and 3.9 , and 4.2 and $6.7 \mathrm{~g} \mathrm{~m}^{-2} \mathrm{yr}^{-1}$, respectively, yielding a near neutral $\mathrm{C}$ balance in both years. However, this balance had considerable uncertainty due to the sensitivity of the ecosystem scale exchange to the spatial extrapolation of exchanges at the topographic unit scale (Waddington \& Roulet, 1997). In the present study, the uncertainties are much less than in Waddington \& Roulet (1997) because the NEE flux obtained by eddy covariance is already spatially averaged and the DOC loss and runoff were measured at the catchment outflow, and not inferred from flownet analysis. Worrall et al. (2003), working on an upland peatland in England, arrived at values similar to ours, but their balance was made up from information on various components from different years and different peatlands. Based on the variations in $\mathrm{NEE}, \mathrm{CH}_{4}$, and DOC export from our study and among other peatland reported in the literature, we question whether this is a good approach.

\section{Comparison of contemporary $C$ balance and past $C$ accumulation}

Our results from two cores demonstrate the need for multiple core assessments of past CARs in order to assess LORCA adequately in a given peatland. Most studies on past $\mathrm{C}$ accumulation in peatlands are based on single, central cores. At Mer Bleue, in the vicinity of the tower, the two cores, MB930 and MB775, give some indication of the variability that can exist within the central part of a peatland. Based on a palynological study by Mott \& Camfield (1969) between the northwestern and central arm of Mer Bleue (see Fig. 1 in Fraser et al., 2001a), $5.2 \mathrm{~m}$ of peat were retrieved dating back ca. 8500 years ago; we are confident that the much higher resolution MB930 core data are effectively representative of the overall CAR for most of the nontreed central part of the peatland. Consequently, a mean LORCA of about $20 \mathrm{~g} \mathrm{C} \mathrm{m}^{-2} \mathrm{yr}^{-1}$ probably applies to the entire peatland between 3000 and 400 years ago, and to the vicinity of the tower.

In a synthesis of $\mathrm{C}$ accumulation in western Canadian peatlands, Vitt et al. (2000) estimate a mean rate of $19.4 \mathrm{~g} \mathrm{~m}^{-2} \mathrm{yr}^{-1}$, but there was no disaggregation of accumulation rates by peatland type. Turunen et al. 
(2004) reports a mean LORCA for 15 ombrotrophic bogs in eastern Canada of $19 \pm 8 \mathrm{~g} \mathrm{~m}^{-2} \mathrm{yr}^{-1}$, while Gorham et al. (2003) report a mean and median dry matter accumulation rate of 47 and $50 \mathrm{~g} \mathrm{~m}^{-2} \mathrm{yr}^{-1}$, respectively, for a widely dispersed sample of 32 North American peatlands. Assuming a 50\% C concentration, they are equivalent to a CAR of 24 and $25 \mathrm{~g} \mathrm{~m}^{-2} \mathrm{yr}^{-1}$, or 22 and $23 \mathrm{~g} \mathrm{~m}^{-2} \mathrm{yr}^{-1}$ if a C concentration of $46 \%$ is used, as we have done. Turunen et al. (2002) analysed peat depth, age and $C$ contents for over 1000 Finnish peatlands and estimated an overall CAR for undrained peatlands of $18.6 \mathrm{~g} \mathrm{~m}^{-2} \mathrm{yr}^{-1}$, of which bogs with a CAR of $20.8 \mathrm{~g} \mathrm{~m}^{-2} \mathrm{yr}^{-1}$, formed a subset of the sample. Based on these estimates, the Mer Bleue CARs are close to the mean for northern hemisphere bogs and fit well within the variance and range reported in regional surveys.

We know of no other studies that have directly compared a multiyear contemporary $\mathrm{C}$ accumulation estimate with a palaeoaccumulation estimate for the same peatland. For the Mer Bleue peatland the 6-year mean contemporary CAR is not statistically different from the LORCA obtained from the two peatlands cores (i.e. no difference between the contemporary $\mathrm{C}$ balance and the past $C$ accumulation of the last 3000 years). It would be very difficult to obtain a statistical difference given the large interannual variability in NEE, but it is not likely that we would be able to obtain a sufficiently long record of contemporary $\mathrm{C}$ exchange to reduce the variance to much less than $20-30 \mathrm{~g} \mathrm{~m}^{-2} \mathrm{yr}^{-1}$.

\section{Conclusions}

In this paper, we report the results from an intensive multiyear study of a single peatland in the midcontinental cool-temperate climate zone of North America. How applicable are the results of this study to northern peatlands in general? Mer Bleue represents an ombrotrophic peatland, which is ubiquitous throughout northern North America, Europe, and Asia. These peatland ecosystems share similar developmental and ecological characteristics due to a certain degree of selfregulatory feedback between their hydrology and the processes that control peat accumulation (Gorham, 1991; Hilbert et al., 2000; Belyea \& Baird, 2006). However, within the context of this generality, ombrotrophic peatland can display a wide variety of morphologies depending on their specific climatic and physiographic setting. Mer Bleue has a midcontinental location. We, therefore, would not expect our results to apply to ombrotrophic peatlands located in Maritime settings were there is a large annual precipitation excess (500 to $>1000 \mathrm{~mm} \mathrm{yr}^{-1}$ ) over evapotranspiration. Despite this last qualification, a recent $\mathrm{CO}_{2}$ exchange study on an Atlantic blanket bog in western Ireland has a very similar NEE to Mer Bleue (Sottocornola \& Kiely, 2005) even though the ecology of the blanket bog is very different than a continental bog.

We draw two conclusions that should apply generally to all ombrotrophic peatlands, and an additional conclusion more specific to Mer Bleue, but that should be tested widely by others on a variety of northern peatlands:

1. To determine the contemporary $\mathrm{C}$ balance of a peatland, NEE, $\mathrm{CH}_{4}$ flux, and DOC export are all required. As DOC export and net $\mathrm{C}$ accumulation can be the same size in a given year, neglecting DOC in a peatland $\mathrm{C}$ balance prohibits determining whether the balance is significantly different from 0 : the measurement of DOC input and export is as important as the continuous record of NEE. Unlike Mer Bleue, where $\mathrm{CH}_{4}$ emission is relatively small, the magnitude of the $\mathrm{CH}_{4}$ flux in many peatlands is of the same order as DOC and $\Delta C_{\text {org }}$ and its neglect raises the same concern.

2. The estimates of exchanges produced in this study after 6-years of continuous and extensive measurements are quite close to those inferred by Gorham (1991), even though he had very little data on which to draw. He had to assume that the past CAR was a reasonable estimate of the contemporary rate, since when he did his synthesis there were no reliable estimates of NEE for northern peatlands. Our study provides quantitative confirmation of Gorham's inferences, at least for one bog. It would not be reasonable to assume that our results are representative for other peatlands where there has been no disturbance or a major shift in climate and/or the physical/ecological setting. Unfortunately, with analysing peat cores and constructing a peatland $\mathrm{C}$ balance as we have done in this study, there is no obvious way to conclude a priori whether or not the past CAR is applicable to the present. Testing the universality of no significant difference between the past and present CAR requires replications of our study across a diverse set of ecoclimatic regions and other peatland types.

3. We cannot determine if we have measured the components of the $C$ balance of Mer Bleue long enough to determine an acceptably accurate contemporary mean. Using 5 of the 6 years, either individually or in combination, we would have come to very different conclusions about the sink/source function of Mer Bleue than what the 6-year mean suggests. The conclusions could have ranged from a contemporary sink three to four times greater than the past accumulation rates (e.g. $-70-90 \mathrm{~g} \mathrm{C} \mathrm{m}^{-2} \mathrm{yr}^{-1}$ ) to a net source of C (e.g. $10-20 \mathrm{~g} \mathrm{C} \mathrm{m}^{-2} \mathrm{yr}^{-1}$ ). The combination of climate conditions Mer Bleue experienced 
over the 6 years of study captures a wide range of precipitation, but is biased towards warmer conditions. However, this is not something we are likely to avoid given the trend in increasing temperatures observed over most of the northern hemisphere for the last century, and particularly, the last 40-50 years.

\section{Acknowledgements}

We thank the following for their extensive help in the field and laboratory: S. Admiral, H. Asnong, G. Crosby, D. van Dyke, H. Elliot, J-M. Ferrone, C. Fraser, S. Giffin, R. Hember, C. Honeywill, A. C. Larouche, N. McQuaid, N. Morasse, M. Murphy, S. Pappas, K. Rich, C. Roehm, H. Stewart, and especially Mike Dalva and Doug Barr. We also thank Gershon Rother and the staff of the National Capital Commission for their logistic help, for permission to use Mer Bleue and their ongoing efforts to conserve and educate the public about the wonderful peatland. Professor R. S. Clymo and another reviewer's comments were greatly appreciated. The work at Mer Bleue was first supported by an NSERC Strategic Grant (1996-2000), then NSERC, CFCAS, and BIOCAP Canada through support to Fluxnet-Canada Research Network (2001 and on going), and individual NSERC Discovery Grants to N. T. R., T. R. M., P. M. L., and P. J. H. R., and individual NASA and NSF grants to J. L. B.

\section{References}

Albritton DL, Meira Filho LG (2001) Technical Summary of the Working Group I to the Third Assessment Report of the Intergovernmental Panel of Climate Change. Intergovernmental Panel of Climate Change, Cambridge University Press, Cambridge, UK, pp. 21-83.

Alm J, Saarnio S, Nykanen $\mathrm{H}$ et al. (1999a) Winter $\mathrm{CO}_{2}, \mathrm{CH}_{4}$ and $\mathrm{N}_{2} \mathrm{O}$ fluxes on some natural and drained boreal peatlands. Biogeochemistry, 44, 163-186.

Alm J, Schulman L, Walden J et al. (1999b) Carbon balance of a boreal bog during a year with an exceptionally dry summer. Ecology, 80, 161-174.

Anderson TW (1988) Late Quaternary pollen stratigraphy of the Ottawa valley - Lake Ontario region and its application in dating the Champlain Sea. In: The Late Quaternary Development of the Champlain Sea Basin. Special Paper, Vol. 35 (ed. Gadd NR), pp. 207-224. Geological Association of Canada, Canada.

Arneth A, Kurbatova J, Kolle O et al. (2002) Comparative ecosystem-atmosphere exchange of energy and mass in a European Russian and central Siberian bog II: interseaonal and interannual variability of $\mathrm{CO}_{2}$ fluxes. Tellus, 54B, 514-530.

Auer V (1930) Peat bogs in southeastern Canada, Canada Department of Mines, Ottawa. Memoir, 162, 32 pp.

Aurela M, Laurila T, Tuovinen J (2002) Annual $\mathrm{CO}_{2}$ balance of a subarctic fen in northern Europe: Importance of the wintertime efflux. Journal of Geophysical Research, 107, 4607, doi: 10.1029/2002JD002055.

Aurela M, Laurila T, Touvinen J (2004) Timing of snow melt controls the annual $\mathrm{CO}_{2}$ balance in a subarctic fen. Geophysical Research Letters, 31, L16119, doi:10.1029/2004GL020315.

Barr AG, Black TA, Hogg EH et al. (2004) Inter-annual variability in the leaf area index of a boreal aspen-hazelnut forest in relation to net ecosystem production. Agricultural and Forest Meteorology, 126, 237-255.

Beaudoin A (2003) A comparison of two methods for estimating the organic content of sediments. Journal of Paleolimnology, 29, 387-390.

Belyea LR, Baird AJ (2006) Beyond "the limits to peat bog growth": cross-scale feedback in peatland development. Ecological Monographs, 76, 299-322.

Billett MF, Palmer SM, Hope D et al. (2004) Linking landatmosphere-stream carbon fluxes in a lowland peatland system. Global Biogeochemical Cycles, 18, GB1084, doi: 10.1029/ 2003 GB002058.

Brovkin V, Bendsten J, Claussen M et al. (2002) Carbon cycle, vegetation and climate dynamics in the Holocene: experiments with the CLIMBER-2 Model. Global Biogeochemical Cycles, 16, 1139-1150.

Bubier J, Frolking S, Crill P et al. (1999) Net ecosystem productivity and its uncertainty in a diverse boreal peatland. Journal of Geophysical Research, 104, 27683-27692.

Bubier J, Moore T, Savage K et al. (2005) A comparison of methane flux in a boreal landscape between a dry and a wet year. Global Biogeochemical Cycles, 19, GB1024, doi: 10.1029/ $2004 G B 002351$.

Bubier J, Moore TR, Crosby G (2006) Fine-scale vegetation distribution in a cool temperate peatland. Canadian Journal of Botany, 82, 1292-1313.

Clymo RS, Turunen J, Tolonen K (1998) Carbon accumulation in peatlands. Oikos, 81, 368-388.

Coüteaux M (1962) Notes sur le prélèvement et la préparation de certains sédiments. Pollen et Spores, 4, 317-322.

Dalva M, Moore TR (1991) Sources and sinks of dissolved organic carbon in a forested swamp catchment. Biogeochemistry, 15, 1-19.

Dawson JC, Billett MF, Hope D et al. (2004) Sources and sinks of aquatic carbon in a peatland stream continuum. Biogeochemistry, 70, 71-92.

Dean WE (1974) Determination of carbonate and organic matter in calcareous sediments and sedimentary rocks by loss on ignition. Comparison with other methods. Journal of Sedimentary Petrology, 44, 242-248.

Elson JA, Elson JB (1969) Phases of the Champlain sea indicated by littoral mollusks. Geological Society of America Bulletin, 70, 1596.

Fraser CJD, Roulet NT, Lafleur PM (2001a) Groundwater flow patterns in a large peatland. Journal of Hydrology, 246, 142-154.

Fraser CJD, Roulet NT, Moore TR (2001b) Hydrology and dissolved organic carbon biogeochemistry in an ombrotrophic bog. Hydrological Processes, 15, 3151-3166.

Friborg T, Soegaard H, Christensen TR et al. (2003) Siberian wetlands: where a sink is a source. Geophysical Research Letters, 30, 2129-2132.

Gorham E (1991) Northern peatlands: role in the carbon budget and probable responses to global warming. Ecological Applications, 1, 182-195.

Gorham E, Janssens J, Glaser P (2003) Rates of peat accumulation during the postglacial period in 32 sites from Alaska to Newfoundland, with special emphasis on northern Minnesota. Canadian Journal of Botany, 81, 429-438.

Hilbert DW, Roulet NT, Moore TR (2000) Modelling and analysis of peatlands as dynamical systems. Journal of Ecology, 88, 230-242. 
Hope D, Billett MF, Cresser MS (1997) Export of organic carbon in two rivers systems in NE Scotland. Journal of Hydrology, 193, 61-82.

Humphreys ER, Black TA, Morgenstern K et al. (2005) Net ecosystem production of a Douglas-fir stand for 3 years following clearcut harvesting. Global Change Biology, 11, 450-464.

Ingram HAP (1978) Soil layers in mires: function and terminology. Journal of Soil Science, 29, 224-227.

Jowsey PC (1966) An improved peat sampler. The New Phytologist, 65, 245-248.

Joyal R (1970) Description de la tourbière à Sphaignes Mer Bleue près d'Ottawa. 1. Végétation. Canadian Journal of Botany, 48, $1405-1418$.

Korhola A, Alm J, Tolonen K et al. (1996) Three-dimensional reconstruction of carbon accumulation and $\mathrm{CH} 4$ emission during nine millennia in a raised mire. Journal of Quaternary Science, 11, 161-165.

Lafleur PM, McCaughey JH, Joiner DW et al. (1997) Seasonal trends in energy, water and carbon dioxide fluxes at a northern boreal wetland. Journal of Geophysical Research, 102, 29009-29020.

Lafleur PM, Roulet NT, Admiral S (2001) The annual cycle of $\mathrm{CO}_{2}$ exchange at a boreal bog peatland. Journal of Geophysical Research, 106, 3071-3081.

Lafleur PM, Roulet NT, Bubier JL et al. (2003) Interannual variability in the peatland-atmosphere carbon dioxide exchange at an ombrotrophic bog. Global Biogeochemical Cycles, 17, 1036, doi: 10.1029/2002GB001983.

Lavoie M, Richard PJH (2000a) The role of climate on the developmental history of Frontenac Peatland, southern Quebec. Canadian Journal of Botany, 78, 668-684.

Lavoie M, Richard PJH (2000b) Paléoécologie de la tourbière du lac Malbaie, dans le massif des Laurentides (Québec): évaluation du rôle du climat sur l'accumulation de la tourbe. Géographie physique et Quaternaire, 54, 169-185.

Likens GE, Bormann FH (1995) Biogeochemistry of a Forested Ecosystem. Springer-Verlag, New York.

Lovett GM, Cole JJ, Pace ML (2006) Is net ecosystem production equal to ecosystem carbon accumulation? Ecosystem, 9, 152-155.

Melloh R, Crill P (1996) Winter methane dynamics in a temperate peatland. Global Biogeochemical Cycles, 10, 247-254.

Moore TR, Bubier J, Frolking $S$ et al. (2002) Plant biomass and production and $\mathrm{CO}_{2}$ exchange in an ombrotrophic bog. Journal of Ecology, 90, 25-36.

Moore TR, Roulet NT (1995) Methane emissions from Canadian peatlands. In: Soils and Global Change (eds Lal R, Kimble J, Levine E, Stewart BA), pp. 153-164. Lewis Publishers, Boca Raton.

Moore TR, Roulet NT, Waddington JM (1998) Uncertainty in predicting the effect of climatic change on the carbon cycling of Canadian peatlands. Climatic Change, 40, 229-245.

Morgenstern K, Black TA, Humphreys ER et al. (2004) Annual variations in carbon sequestration during an $\mathrm{El} \mathrm{Niño/La} \mathrm{Niña}$ cycle in a coastal Douglas-fir forest. Agricultural and Forest Meteorology, 123, 201-219.

Mott RJ, Camfield M (1969) Palynological Studies in the Ottawa Area. Geological Survey of Canada, Ottawa, pp. 1-16.

Nilsson M, Mikkela C, Sundh I et al. (2001) Methane emissions from Swedish mires: national and regional budgets and de- pendence on mire vegetation. Journal of Geophysical Research, 106, 20847-20860.

Nordstroem C, Soegaard H, Christensen TR et al. (2001) Seasonal carbon dioxide balance and respiration of a high-arctic fen ecosystem in NE-Greenland. Theoretical and Applied Climato$\log y, 70,149-166$.

Richard PJH, Occhietti S (2005) ${ }^{14} \mathrm{C}$ chronology for ice retreat and inception of Champlain Sea in the St. Lawrence Lowlands, Canada. Quaternary Research, 63, 353-358.

Roehm C, Roulet NT (2003) The seasonal contribution of $\mathrm{CO}_{2}$ fluxes in the annual $\mathrm{C}$ budget of a northern bog. Global Biogeochemical Cycles, 17, 291-299.

Schimel DS (1995) Terrestrial ecosystems and the carbon cycle. Global Change Biology, 1, 77-91.

Schulze E-D, Prokuschkin A, Arneth A et al. (2002) Net ecosystem productivity and peat accumulation in a Seberian Aapa mire. Tellus, 54B, 531-536.

Shurpali NJ, Verma SB, Kim J et al. (1995) Carbon dioxide exchange in a peatland ecosystem. Journal of Goephysical Research, 100, 14319-14326.

Sottocornola M, Kiely G (2005) An Atlantic bog is a modest $\mathrm{CO}_{2}$ sink. Geophysical Research Letters, 32, L23804, doi:10.1029/ 2005 GL02473.

Suyker AE, Verma SB, Arkebaur TJ (1997) Season-long measurements of carbon dioxide exchange in a boreal fen. Journal of Geophysical Research, 102, 29021-29028.

Tanner CB, Thurtell GW (1969) Anemoclinometer Measurements of Reynolds Stress and Heat Transport in the Atmospheric Surface Layer. ECOM 66-G22-F. University of Wisconsin, Madison, WI.

Tolonen K, Turunen J (1996) Accumulation rates of carbon in mires in Finland and implications for climate change. Holocene, 6, 171-178.

Turunen J, Roulet NT, Moore TR et al. (2004) Nitrogen deposition and increased carbon accumulation in ombrotrophic peatlands in eastern Canada. Global Biogeochemical Cycles, 18, GB3002, doi: 10.1029/2003GB002154.

Turunen J, Tomppo E, Tolonen K et al. (2002) Estimating carbon accumulation rates of undrained mires in Finland - application to boreal and subarctic regions. The Holocene, 12, 69-80.

Vitt DH, Halsey LA, Bauer IE et al. (2000) Spatial and temporal trends in carbon storage of peatlands of continental western Canada through the Holocene. Canadian Journal of Earth Sciences, 37, 683-693.

Vourlitis GL, Oechel WC (1997) Landscape-scale $\mathrm{CO}_{2}, \mathrm{H}_{2} \mathrm{O}$ vapour and energy flux of moist-wet coastal tundra ecosystems over two growing seasons. Journal of Ecology, 85, 575-590.

Waddington J, Roulet NT (1997) The hydrological movement of DOC, dissolved $\mathrm{CO}_{2}$ and $\mathrm{CH}_{4}$ in a northern Scandinavian peatland. Journal of Hydrology, 191, 122-138.

Waddington MJ, Roulet NT (2000) Carbon balance of a boreal patterned peatland. Global Change Biology, 6, 87-97.

Whiting GJ (1994) $\mathrm{CO}_{2}$ exchange in the Hudson Bay Lowland: community characteristics and multispectral reflectance properties. Journal of Geophysical Research, 99, 1519-1528.

Worrall F, Reed M, Warburton J et al. (2003) Carbon budget for a British upland peat catchment. The Science of the Total Environment, 312, 133-146. 